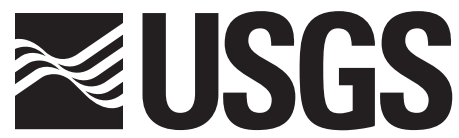

science for a changing world

Prepared in cooperation with the U.S. Bureau of Reclamation

\title{
Determination of Total Mercury in Fillets of Sport Fishes Collected from Folsom Reservoir, California, 2006
}

Open-File Report 2007-1078 



\section{Determination of Total Mercury in Fillets of Sport Fishes Collected from Folsom Reservoir, California, 2006}

By Thomas W. May and William G. Brumbaugh

Prepared in cooperation with the U.S. Bureau of Reclamation

Open-File Report 2007-1078

U.S. Department of the Interior

U.S. Geological Survey 


\section{U.S. Department of the Interior DIRK KEMPTHORNE, Secretary}

\section{U.S. Geological Survey \\ Mark D. Myers, Director}

U.S. Geological Survey, Reston, Virginia 2007

For product and ordering information:

World Wide Web: http://www.usgs.gov/pubprod

Telephone: 1-888-ASK-USGS

For more information on the USGS - the Federal source for science about the Earth, its natural and living resources, natural hazards, and the environment:

World Wide Web: http://www.usgs.gov

Telephone: 1-888-ASK-USGS

Suggested citation:

May, T.W., and Brumbaugh, W.G., 2007, Determination of total mercury in fillets of sport fishes collected from Folsom Reservoir, California, 2006: U.S. Geological Survey Open-File Report 2007-1078, 6 p.

Any use of trade, product, or firm names is for descriptive purposes only and does not imply endorsement by the U.S. Government.

Although this report is in the public domain, permission must be secured from the individual copyright owners to reproduce any copyrighted material contained within this report. 


\section{Contents}

Introduction.

\section{Tables}

1. Total mercury concentrations in fillets of sport fishes from Folsom Reservoir, California, 2006 ........................................

2. Total mercury concentrations in dry tissue powders submitted with whole-body fish samples, 2006 ..............................4

\section{Conversion Factors}

\begin{tabular}{lcl}
\hline \multicolumn{1}{c}{ Multiply } & By & To obtain \\
\hline \multicolumn{1}{c}{ Mass } & \\
\hline gram $(\mathrm{g})$ & 0.03527 & ounce $(\mathrm{oz})$ \\
milligram $(\mathrm{mg})$ & .000035 & ounce $(\mathrm{oz})$ \\
\hline & Length & \\
\hline millimeter $(\mathrm{mm})$ & 0.0394 & inches (in) \\
\hline
\end{tabular}

Temperature in degrees Celsius $\left({ }^{\circ} \mathrm{C}\right)$ may be converted to degrees Fahrenheit $\left({ }^{\circ} \mathrm{F}\right)$ as follows: ${ }^{\circ} \mathrm{F}=\left(1.8 \times{ }^{\circ} \mathrm{C}\right)+32$

Concentrations of chemical constituents in solid materials are given in microgram per gram $(\mu \mathrm{g} / \mathrm{g})$. 


\title{
Determination of Total Mercury in Fillets of Sport Fishes Collected from Folsom Reservoir, California, 2006
}

\author{
By Thomas W. May and William G. Brumbaugh
}

\begin{abstract}
This report presents the results of a study by the U.S. Geological Survey, done in cooperation with the U.S. Bureau of Reclamation, to determine mercury concentrations in selected sport fishes from Folsom Reservoir in California. Fillets were collected from each fish sample, and after homogenization and lyophilization of fish fillets, mercury concentrations were determined with a direct mercury analyzer utilizing the process of thermal combustion-gold amalgamation atomic absorption spectroscopy. Mercury concentrations in fillets ranged from 0.031 to 0.20 micrograms per gram wet weight in rainbow trout (Oncorhynchus mykiss) samples and 0.071 to 0.16 micrograms per gram wet weight in bluegill (Lepomis macrochirus) samples. Mercury concentration was 0.98 microgram per gram wet weight in a single spotted bass (Micropterus punctulatus) sample, which was the only one in the sample set which exceeded the U.S. Environmental Protection Agency's fish consumption advisory of 0.30 microgram per gram wet weight.
\end{abstract}

\section{Introduction}

Mercury is a byproduct of the extensive gold mining performed in the Sierra Nevada Mountains of California in the nineteenth century. After being discarded by miners, the residual mercury was gradually released into the downstream environment, including that of the American River. Folsom Reservoir is on the American River northeast of Sacramento and supports recreational fishing for several cold and warm water fish species, including rainbow trout (Oncorhynchus mykiss), brown trout (Salmo trutta), bass, catfish, crappie, perch, and bluegill (Lepomis macrochirus). Created by Folsom Dam, this reservoir is managed by the California Department of Parks and Recreation under an agreement with the U.S. Bureau of Reclamation (USBR).

The U.S. Geological Survey (USGS) conducted a study in cooperation with the USBR to determine the concentrations of mercury in selected sport fishes from Folsom Reservoir. The California Department of Fish and Game (CDFG), along with USBR personnel, conducted all fish collections. The USBR will use the data from this study to make future management decisions concerning fish harvests from Folsom Reservoir. 


\section{Sample History}

A shipment of 14 whole-body fish and 4 dry tissue powder samples collected by USBR was received by the USGS on June 28, 2006. The fish samples were collected by line fishing and consisted of 13 rainbow trout and 1 spotted bass (Micropterus punctulatus). Upon receipt, the samples were assigned USGS batch number 1264 and USGS identification numbers 37049-37066. A second shipment arrived on August 16, 2006 that consisted of nine whole-body bluegill sunfish and two dry tissue powder samples. This shipment was assigned USGS batch number 1285 and USGS identification numbers 37724-37734. Before receipt by the USGS, all whole-body fish samples had organs removed (liver, spleen, and one kidney) by the CDFG for a separate study. The USBR requested that the USGS determine the fork length on all fish and total length on rainbow trout, then remove a fillet sample, and determine percent moisture and total mercury on all submitted samples.

\section{Methods}

\section{Homogenization and Lyophilization}

All methods and procedures employed followed approved USGS Standard Operating Procedures. Filleting of the larger fish was conducted with a titanium knife; smaller fish were filleted using a ceramic knife. A fillet was collected from one side of all fish, except for bluegill, which had fillets removed from both sides to provide a more suitable biomass. All fillet samples were minced with a titanium knife. Homogenized samples and tissue reference materials were lyophilized with a Virtis Genesis ${ }^{\circledR}$ 35EL freeze dryer, and percent moisture was determined as part of the lyophilization procedure. Once dried, fillet samples were further homogenized by crushing with a glass rod in a glass sample vial. All dried samples were stored in glass vials in a desiccator.

\section{Instrumental Analysis and Data Reporting}

Mercury was determined with a direct mercury analyzer. With this method, a dried fish sample of approximately $50 \mathrm{mg}$ (milligrams) was combusted in a stream of oxygen. All mercury in the sample was volatilized and trapped by amalgamation on a gold substrate and thermally desorbed and quantitated by atomic absorption spectrophotometry (U.S. Environmental Protection Agency, 2003). The entire sequence was conducted with a Milestone Direct Mercury Analyzer (DMA-80) equipped with an automated sample carousel. Duplicate determinations were conducted for each sample, and the mean of the two analyses was reported. However, if the relative percent difference (RPD) among duplicates exceeded 20 percent, an additional analysis was performed, and the concentration expressed as the mean of all three analyses. The mercury concentrations measured in dried fillet samples was converted to wet weight for reporting based on moisture contents determined by lyophilization, but concentrations of samples received as dry powders (tissue reference materials) were reported "as received." Residual moisture of homogenized, desiccator-stored fish fillet tissue typically is between 3 and 5 percent. No attempt was made to apply a correction for residual moisture of individual dry samples because the mercury analyzer was calibrated with dried certified reference tissues having similar ranges of moisture content. The uncertainty of reported wet-weight concentrations, potentially because of moisture differences among the individual dried unknown samples and the certified reference samples used for the calibration, is expected to be considerably less than the overall method uncertainty [about \pm (plus or minus) 5 to 10 percent for mean concentrations well above the method 
quantitation limit]. Furthermore, the uncertainty associated with moisture variation among dry sample determinations should be no greater than the uncertainty associated with moisture variation among fresh or frozen fish fillet sample analyses.

\section{Results and Discussion}

Fork length, total length, percent moisture, and mean concentrations of total mercury measured in fish fillet samples collected from various sport fishes of Folsom Reservoir are presented in table 1. Percent moisture in fillets ranged from 76.7 to 81.1 percent and averaged 79.1 percent. Mercury concentrations in rainbow trout samples ranged from 0.031 to $0.20 \mu \mathrm{g} / \mathrm{g}$ (micrograms per gram) wet weight and averaged $0.099 \mu \mathrm{g} / \mathrm{g}$. In bluegill samples, mercury concentrations ranged from 0.071 to 0.16 $\mu \mathrm{g} / \mathrm{g}$ wet weight and averaged $0.11 \mu \mathrm{g} / \mathrm{g}$. The highest mercury concentration was detected in the single spotted bass sample $(0.98 \mu \mathrm{g} / \mathrm{g}$ wet weight), which was well above the U.S. Environmental Protection Agency's consumption advisory of $0.30 \mu \mathrm{g} / \mathrm{g}$ wet weight (U.S. Environmental Protection Agency, 2001). This was the only fish sample that exceeded this consumption advisory guideline.

Table 1. Total mercury concentrations in fillets of sport fishes from Folsom Reservoir, California, 2006.

[USGS, U.S. Geological Survey; ID, identification; mm, millimeter; n, number; $\mu \mathrm{g} / \mathrm{g}$, micrograms per gram wet weight; --, no data]

\begin{tabular}{|c|c|c|c|c|c|c|c|}
\hline $\begin{array}{c}\text { USGS ID } \\
\text { number }\end{array}$ & $\begin{array}{c}\text { Field/lab } \\
\text { ID }\end{array}$ & Species & $\begin{array}{c}\text { Fork } \\
\text { length } \\
(\mathrm{mm})\end{array}$ & $\begin{array}{l}\text { Total } \\
\text { length } \\
(\mathrm{mm})\end{array}$ & $\begin{array}{l}\text { Percent } \\
\text { moisture }\end{array}$ & $\mathbf{n}$ & $\begin{array}{c}\text { Mean total } \\
\text { mercury } \\
(\mu \mathrm{g} / \mathrm{g})\end{array}$ \\
\hline 37050 & FLF051 & Rainbow trout & 335 & 365 & 81.1 & 2 & 0.094 \\
\hline 37051 & FLF052 & Rainbow trout & 314 & 338 & 78.4 & 2 & 0.050 \\
\hline 37052 & FLF053 & Rainbow trout & 398 & 405 & 79.1 & 2 & 0.20 \\
\hline 37053 & FLF054 & Rainbow trout & 307 & 337 & 79.9 & 2 & 0.11 \\
\hline 37054 & FLF055 & Rainbow trout & 265 & 280 & 77.0 & 2 & 0.082 \\
\hline 37055 & FLF056 & Rainbow trout & 302 & 315 & 78.0 & 2 & 0.031 \\
\hline 37056 & FLF057 & Rainbow trout & 273 & 288 & 77.8 & 2 & 0.092 \\
\hline 37057 & FLF058 & Rainbow trout & 308 & 325 & 76.7 & 2 & 0.13 \\
\hline 37060 & FLF061 & Rainbow trout & 310 & 345 & 79.5 & 2 & 0.095 \\
\hline 37061 & FLF062 & Rainbow trout & 242 & 254 & 77.3 & 2 & 0.091 \\
\hline 37062 & FLF063 & Rainbow trout & 302 & 315 & 78.9 & 2 & 0.12 \\
\hline 37063 & FLF064 & Rainbow trout & 285 & 305 & 78.6 & 2 & 0.082 \\
\hline 37064 & FLF065 & Rainbow trout & 343 & 360 & 77.7 & 2 & 0.11 \\
\hline 37065 & FLF066 & Spotted bass & 413 & 435 & 79.4 & 2 & 0.98 \\
\hline 37725 & FLF067B & Bluegill & 125 & -- & 79.6 & 2 & 0.16 \\
\hline 37726 & FLF068 & Bluegill & 153 & -- & 78.5 & 2 & 0.14 \\
\hline 37727 & FLF069 & Bluegill & 149 & -- & 80.5 & 2 & 0.095 \\
\hline 37728 & FLF070 & Bluegill & 124 & -- & 80.8 & 2 & 0.076 \\
\hline 37729 & FLF071 & Bluegill & 130 & -- & 79.2 & 2 & 0.086 \\
\hline 37730 & FLF072 & Bluegill & 122 & -- & 79.4 & 2 & 0.071 \\
\hline 37731 & FLF073 & Bluegill & 137 & -- & 80.4 & 2 & 0.093 \\
\hline 37732 & FLF074 & Bluegill & 129 & -- & 80.7 & 2 & 0.15 \\
\hline 37733 & FLF075 & Bluegill & 145 & -- & 80.0 & 2 & 0.15 \\
\hline
\end{tabular}


Percent moisture and mean concentrations of total mercury in submitted dry tissues are presented in table 2. Percent moisture ranged from 4.1 to 8.9 percent. Mercury concentrations ranged from 0.5 to $2.93 \mu \mathrm{g} / \mathrm{g}$ dry weight. As mentioned earlier, mercury concentrations were not corrected for the residual moisture because the DMA-80 is calibrated using dried reference tissue powders with comparable residual moisture values.

Table 2. Total mercury concentrations in dry tissue powders submitted with whole-body fish samples, 2006.

[USGS, U.S. Geological Survey; ID, identification; n, number; $\mu \mathrm{g} / \mathrm{g}$, microgram per gram as received]

\begin{tabular}{ccccc}
\hline $\begin{array}{c}\text { USGS ID } \\
\text { number }\end{array}$ & $\begin{array}{c}\text { Field/lab } \\
\text { ID }\end{array}$ & $\begin{array}{c}\text { Percent } \\
\text { moisture }\end{array}$ & $\mathbf{n}$ & $\begin{array}{c}\text { Mean total } \\
\text { mercury } \\
(\mathbf{p g} / \mathbf{g})\end{array}$ \\
\hline & & & & \\
37049 & FLF050 & 8.9 & 2 & 0.50 \\
37058 & FLF059 & 7.4 & 2 & 0.51 \\
37724 & FLF067A & 7.4 & 2 & 0.52 \\
37734 & FLF075A & 6.9 & 2 & 0.52 \\
37059 & FLF060 & 4.1 & 2 & 2.92 \\
37066 & FLF067 & 4.3 & 2 & 2.93 \\
\hline
\end{tabular}

\section{Quality Control}

The samples were handled in one group or block through the instrumental analysis. Quality control included blanks, replicates, pre-combustion spikes, and tissue reference materials. During the instrumental run, additional quality control included independent calibration verification checks. For the group or block of samples, two independent calibration verification samples [National Research Council Canada (NRCC) DOLT-3 and International Atomic Energy Agency (IAEA) 407] were analyzed at the beginning and end of the instrumental run to confirm the calibration status of the DMA80 system; each measured calibration sample was within \pm 10 percent of the certified concentration. Five reference tissues were analyzed for mercury: NRCC DORM-2 [n=2 (2 samples)], National Institute of Standards and Technology (NIST) RM50 ( $\mathrm{n}=2)$, IAEA $407(\mathrm{n}=2)$, NRCC DOLT-3 ( $\mathrm{n}=2)$, and NIST $2976(n=2)$. Recoveries of mercury were within certified or recommended ranges for all NRCC DORM2 and IAEA 407 materials and for one NIST RM50 material. Recoveries were 95 percent for both NIST 2976 materials and 99 percent for one NIST RM50 material. Recoveries of mercury in NRCC DOLT-3 were 102 percent and 104 percent. Method precision can be estimated from the RPD from the duplicate analysis of tissue samples or as percent relative standard deviation (RSD) from triplicates. The overall mean RPD \pm the standard deviation for all fish fillets samples $(n=22)$ was 4.3 percent \pm 2.2 , and for tissue powders $(n=6)$ was 4.1 percent \pm 2.4 . Furthermore, RPDs were less than 8 percent for all but one sample. One fish fillet sample exhibiting an RPD greater than 20 percent was analyzed again to obtain a triplicate analysis. Percent RSDs from triplicate analyses of this and one other arbitrarily selected fish fillet sample were 27 percent and 1.8 percent. Percent recovery of methylmercury hydroxide from precombustion tissue spikes $(n=4)$ ranged from 104 to 115 percent and averaged 109 percent. Although all 
spike recoveries were above 100 percent, the mean recovery was well within quality control protocol target limits (80 to 120 percent). Moreover, spike recoveries are not necessarily the best indicator of accuracy for the DMA-80 method because the instrumental response for liquids is sometimes slightly different than for solids. Blank equivalent concentrations (BEC) for total mercury exceeded the method detection limit for one of the two determinations, but the lowest sample concentration $(0.031 \mu \mathrm{g} / \mathrm{g}$ wet weight) was about eight times the highest BEC concentration $(0.004 \mu \mathrm{g} / \mathrm{g}$ wet weight $)$. The instrument detection limit was $0.0006 \mu \mathrm{g} / \mathrm{g}$ wet weight mercury. The method detection limits were 0.0009 and $0.005 \mu \mathrm{g} / \mathrm{g}$ wet weight mercury, and the method quantitation limits were 0.003 and $0.017 \mu \mathrm{g} / \mathrm{g}$ wet weight. Overall, the quality control was within acceptable limits as specified by the USGS.

\section{References Cited}

U.S. Environmental Protection Agency, 2001, Water quality criterion for protection of human healthMethylmercury: Washington, D.C., U.S. Environmental Protection Agency, Office of Water, EPA823-R-01-001, 269 p.

U.S. Environmental Protection Agency, 2003, Draft update IVA of SW-846, 7000 series, Method 7473, Mercury in solids and solutions by thermal decomposition, amalgamation, and atomic absorption spectrophotometry: accessed July, 2005 at URL http://www.epa.gov/epaoswer/hazwaste/test/up4a.htm\#7_series. 
For more information concerning the research described in this report, contact:

U.S. Geological Survey

Columbia Environmental Research Center

4200 New Haven Road

Columbia, M0 65201

(573) 875-5399

http://www.cerc.usgs.gov 
